\title{
Development and evaluation of a multipurpose tool bar for mini tractor suitable for the cropping pattern of middle Gujarat region
}

KAPIL MANDLOI, R. SWARNKAR, YAGNIK C. YOGANANDI, PARTH PATEL AND K.L. DABHI

Received : 26.05.2017; Revised : 13.08.2017; Accepted : 27.08.2017

See end of the Paper for authors' affiliation

Correspondence to :

YAGNIK C. YOGANANDI

Department of Farm

Machinery and Power

Engineering, College of

Agricultural Engineering and

Technology (A.A.U.),

GODHRA (GUJARAT) INDIA
- ABSTRACT : A mini tractor drawn multipurpose tillage tool has been developed by Anand Agricultural University suitable for seed bed preparation at wapsa conditions under sandy loam soil of middle Gujarat Agro-climatic zone in a single operation. The implement consisting of iron ploughs for tillage and clod crusher for breaking clods which is useful for preparation of seed bed in a single pass with a saving of about $20 \%$ in the cost of the operation as compared to the cultivator. Therefore, it is recommended for farmers of the region to prepare the seedbed by using the developed implement.

- KEY WORDS : Mini tractor, Multipurpose, Tillage tool, Clod crusher

- HOW TO CITE THIS PAPER : Mandloi, Kapil, Swarnkar, R., Yoganandi, Yagnik C., Patel, Parth and Dabhi, K.L. (2017). Development and evaluation of a multipurpose tool bar for mini tractor suitable for the cropping pattern of middle Gujarat region. Internat. J. Agric. Engg., 10(2) : 450-456, DOI: $10.15740 / \mathrm{HAS} / \mathrm{IJAE} / \mathbf{1 0 . 2 / 4 5 0 - 4 5 6 .}$ 